\title{
Histopathological and immunophenotypical characterization of canine multicentric lymphoma in Brazil: a study of 203 cases
}

\author{
[Caracterização histopatológica e imunofenotípica do linfoma multicêntrico canino \\ no Brasil: um estudo de 203 casos] \\ P.C. Jark ${ }^{1,2}$, C.P. Fracacio ${ }^{1}$, L.A. Anai ${ }^{2}$, M.C.L. Silva ${ }^{3}$, S.G. Calazans ${ }^{2}$, \\ I.L.S. Senhorello ${ }^{*}$, M.T. Costa ${ }^{2}$, J.L. Sequeira ${ }^{3}$, F.A.R. Sueiro ${ }^{4}$ \\ ${ }^{1}$ Universidade Brazil - Descalvado, SP \\ ${ }^{2}$ Universidade Estadual Paulista - Jaboticabal, SP \\ ${ }^{3}$ Universidade Estadual Paulista - Botucatu, SP \\ ${ }^{4}$ Autônomo - Campinas SP
}

\begin{abstract}
The immunophenotype is regarded as an independent prognostic factor in high-grade lymphomas, seeing that lymphomas of T-cell origin are associated with shorter survival time. Although a number of studies have evaluated the immunophenotypical profile of lymphoma in the USA and Europe, Brazilian research on the matter remains scarce. Exact characterization of the histopathological type is crucial to establish proper treatment and prognosis. This study evaluated the database of immunohistochemistry laboratories that perform immunophenotyping of canine lymphoma in Brazil. A total of 203 cases of multicentric lymphoma were classified according to the WHO classification. Immunophenotyping was able to identify $71.4 \%$ lymphomas of B-cell line, $27.1 \%$ of T-cell line and $1.5 \%$ of non-B cells and non-T cell lines. Diffuse large B-cell lymphoma was the most common with 59.1\% of the cases. Among T-cell lymphomas, lymphoblastic was the most common (11.33\% of the cases). Even though canine lymphomas tend to be high-grade, indolent lymphomas comprised $11.82 \%$ of the cases and T-zone lymphoma was the most prevalent $(8.86 \%)$. The immunophenotype of multicentric lymphoma in Brazil is similar to those in other parts of the world, which suggests similar etiologic factors to the development of this disease.
\end{abstract}

Keywords: dog, lymphoma, immunophenotype

\section{RESUMO}

O imunofenótipo é considerado um fator prognóstico independente em linfomas de alto grau, visto que os linfomas de origem de células T estão associados a menor tempo de sobrevida. Apesar de vários estudos terem avaliado o perfil imunofenotípico do linfoma nos EUA e na Europa, a pesquisa brasileira sobre o assunto ainda é escassa. A caracterização exata do tipo histopatológico é crucial para estabelecer o tratamento e o prognóstico adequados. Este estudo avaliou a base de dados de laboratórios de imunohistoquímica que realizam imunofenotipagem do linfoma canino no Brasil. Um total de 203 casos de linfoma multicêntrico foi classificado de acordo com a classificação da OMS. A imunofenotipagem foi capaz de identificar 71,4\% dos linfomas da linhagem de células B, 27,1\% da linhagem de células $T e$ $1,5 \%$ das linhagens de células não $B$ e não T. O linfoma difuso de grandes células $B$ foi o mais comum em 59,1\% dos casos. Entre os linfomas de células T, o linfoblástico foi o mais comum (11, 33\% dos casos). Embora os linfomas caninos tendam a ser de alto grau, os linfomas indolentes representaram $11,82 \%$ dos casos e o linfoma da zona $T$ foi o mais prevalente $(8,86 \%)$. O imunofenótipo do linfoma multicêntrico no Brasil é semelhante ao de outras partes do mundo, o que sugere fatores etiológicos semelhantes ao desenvolvimento dessa doença.

Palavras-chave: cão, linfoma, imunofenótipo

Recebido em 24 de abril de 2019

Aceito em 26 de setembro de 2019

*Autor para correspondência (corresponding author)

E-mail: salardani@hotmail.com 


\section{INTRODUCTION}

Lymphoma is regarded as the most common hematopoietic neoplasm of dogs and serves as a model of comparison with human non-Hodgkin lymphoma, due to their similarities in frequent histological and immunophenotypical types (Ponce et al., 2010; Vezzali et al., 2010; Curran and Thamm 2016). As with humans, several histopathological classification systems based on morphological findings have been proposed in the last decade to characterize lymphomas. The main objective of these classifications is to correlate histopathological and immunophenotypical findings to biological behavior, in order to obtain information regarding prognosis and individualized treatment (Valli, 2002; Vezzali et al., 2010).

The Kiel classification is based on cytomorphology and immunophenotyping, and it categorizes tumors as either low- or high-grade (Lennert and Feller, 1992). The National Cancer Institute Working Formulation (NCI-WF) defines the architectural patterns of lymphomas as follicular or diffuse and divides subgroups based on survival, regardless of cell type ( $\mathrm{T}$ - or B-cell origin) (NCI, 1982).

The histological classification according to the World Health Organization (WHO) (Jaffe et al., 2008) is constantly being updated (Swerdlow et al., 2016) and was adapted for veterinary medicine (Valli et al., 2002, 2011, 2013). This classification has been used to characterize the tumor in dogs and enables a comparison of results between human and canine lymphomas because it correlates morphology, immunophenotype, and clinical presentation. This in turn facilitates studies of comparative oncology (Vezzali et al., 2010). The results of the WHO classification system used by a group of pathologists with no specialization in hematopathology showed an $83 \%$ success rate, which demonstrates its efficacy for clinical practice (Valli et al., 2013).

According to the WHO classification system, diffuse large B-cell lymphoma is the most frequent histological type in dogs from the United States and Europe. It is also the most common non-Hodgkin lymphoma of humans (Ponce et al., 2010; Valli et al., 2011; Valli et al., 2013). High-grade diffuse large B-cell lymphoma is highly malignant, with survival time of 10-14 months with appropriate chemotherapy (Marconato et al., 2011). Even though most canine lymphomas are high-grade, recent studies suggest prevalence of 14.5-19.6\% of indolent lymphomas in dogs (Ponce et al., 2010; Valli et al., 2013), which are characterized by low progression and longer survival. Treatment often includes less intense protocols compared to high-grade lymphomas (FloodKnapik et al., 2013). Exact characterization of the histological types associated with immunophenotyping is crucial, since they are intimately related to prognosis and treatment (Flood-Knapik et al., 2013; Valli et al., 2013).

American and European literature provide information regarding the characterization of the main histological types as well as the prevalence of multicentric lymphoma in dogs (Ruslander et al., 1997; Modiano et al., 2005; Ponce et al., 2010). Brazilian literature, however, provides only a few studies, most of which were carried out in a relatively small number of subjects (Sueiro et al., 2004). This study is therefore the largest study regarding the histopathological and immunophenotypical classification of canine multicentric lymphoma according to the WHO classification in Brazil and in Latin America.

\section{MATERIAL AND METHODS}

All procedures were approved by the Ethics Committee for Animal Experimentation (CEUA protocol number 0016/6) of Brazil University Descalvado - SP- Brazil. This study assessed the database of an association between immunohistochemistry laboratories that perform immunophenotyping of canine lymphomas in Brazil. Laboratories included were: VETPAT from Campinas, São Paulo State, Brazil; and Histochemistry laboratory at UNESP, Jaboticabal and Botucatu, São Paulo State, Brazil. Data collection from immunohistochemical analyses performed at the laboratories were solely comprised of canine multicentric lymphomas with lymph node evaluation. Other types of neoplasm such as cutaneous, mediastinal, alimentary and extranodal lymphoma were excluded from the study. Lymphomas were classified according to the Histological Classification of Hematopoietic Tumors of Domestic Animals from the WHO (Valli et al., 2011). 
Data regarding sample provenance (from each of the five regions of Brazil) and patient information (breed, age, gender) were charted for descriptive analysis. Immunohistochemistry and immunophenotyping of multicentric lymphomas followed pre-stablished criteria, as follows: cell size, morphology and immunophenotype according WHO (Valli, 2002). Immunohistochemical reactions were performed on paraffin-embedded samples sectioned at $4-\mu \mathrm{m}$. Samples were positively charged and subjected to immunohistochemical reactions using antibodies from Table 1.

Table 1. Clones, dilution and provenance of antibodies used for immunophenotyping of multicentric lymphoma

\begin{tabular}{llll}
\hline Antibody & Clone & Dilution & Manufacturer \\
\hline CD3 & Polyclonal & $1: 300$ & DAKO \\
CD79 $\alpha$ & HM47/A9 & $1: 300$ & DAKO \\
\hline
\end{tabular}

A biotin-free detection reagent (REVEAL) was used for immunohistochemical analysis. Tissue sections were deparaffinized, rehydrated and incubated for 20 minutes in a 5\% solution of hydrogen peroxide in absolute methanol (Synth) for endogenous peroxidase activity blocking. Heat-induced antigen retrieval followed using a sodium citrate buffer ( $\mathrm{pH}$ 6.0) in a pressure cooker. Sections were then washed three times in phosphate-buffered saline (PBS) at $0.01 \mathrm{M}(\mathrm{pH}$ 7.2) for 5 minutes and nonspecific sites were blocked with a blocking buffer for nonspecific reactions (Reveal Spring kit reagent - Cod SPD125).

When positive for CD79a and negative for CD3, lymphomas were considered of B-cell origin, and $\mathrm{T}$-cell origin when positive for CD3 and negative for CD79a. Lymphomas that were negative for both markers were considered as non-B, non- $\mathrm{T}$, or null cell lymphomas.

\section{RESULTS}

From January 2012 to December 2016, 203 cases of multicentric lymphomas according to the WHO classification system were analyzed. Of 159 samples with information about Brazilian regions, $83.6 \%$ were from the southeast, $8.3 \%$ from the south, $6.3 \%$ from the center-west, $1.2 \%$ from the northeast and $0.6 \%$ from the north.

The age of patients was informed in 171 cases, with a mean of 7.8 years (1-15 years) and $15.8 \%$ of patients under 5 years of age. Regarding gender predisposition, $53.7 \%$ of the cases were diagnosed in females, $42.9 \%$ in males and $3.4 \%$ were unspecified. Mongrels were the most affected (47/203), followed by Golden Retrievers (19/203), Boxers (16/203) and Rottweilers $(15 / 203)$ (Table 2).
Lymphomas of B-cell origin were the most prevalent (71.4\%) compared to T-cell lymphomas $(27.1 \%)$ and non-B or non- $\mathrm{T}$ lymphomas (1.5\%). Golden Retrievers were mostly associated with T-cell $(57.9 \%)$ compared to B-cell lymphomas (42.1\%) and Boxers were mostly associated with B-cell lymphomas (56.3\%). Diffuse large B-cell lymphoma was the most frequent histological type, present in 120 of 203 cases $(59.1 \%$ ) (Table 3 ). Among high-grade T-cell lymphomas, lymphoblastic lymphoma of T-cell origin was the most prevalent, with 23 cases $(11.33 \%)$. Indolent lymphomas according to the WHO classification comprised 24 of the 203 cases $(11.82 \%)$, of which T-zone lymphoma was the most frequent $(18 / 203$ cases $-8.86 \%)$, followed by marginal zone B-cell lymphoma $(1.97 \%)$ and follicular lymphoma $(0.98 \%)$. Of the 18 cases of indolent $\mathrm{T}$-cell lymphomas, $44.4 \%$ were diagnosed in Golden Retrievers.

\section{DISCUSSION}

Canine non-Hodgkin lymphoma is the most frequent hematopoietic neoplasm in dogs, and its similarities to human lymphoma renders it a model for comparative oncology. Canine multicentric lymphoma affects middle-aged to elderly patients with no apparent gender predisposition (Modiano et al., 2005; Ponce et al., 2010). A study conducted on 1263 cases of canine lymphoproliferative disorders showed mean age of 9.1 years and more than $90 \%$ of the subjects older than 5 years. These findings corroborate the present study, in which only $15.8 \%$ of the 171 cases with age information were under 5 years old.

The study by Modiano et al. (2005) comprised 87 breeds and a predominance of mongrel dogs (243 
cases), followed by Golden Retrievers (237), Labradors (105), English Cocker Spaniels (47), Rottweilers (47) and Boxers (39). These results are similar to the findings of this study, in which mongrels were the most found, followed by Golden Retrievers, Boxers and Rottweilers.

Table 2. Prevalence of multicentric lymphoma according to breed of affected patients

\begin{tabular}{ll}
\hline Breed & Number of Cases \\
\hline Mongrel & 47 \\
Golden Retriever & 19 \\
Boxer & 16 \\
Rottweiler & 15 \\
Poodle & 10 \\
English Cocker Spaniel & 8 \\
German Shepherd Dog & 6 \\
Miniature Schnauzer & 6 \\
Dachshund & 5 \\
Lhasa apso & 4 \\
Labrador & 4 \\
Yorkshire Terrier & 4 \\
Maltese & 4 \\
Bull Terrier & 3 \\
Brazilian Fila & 3 \\
Basset Hound & 3 \\
Beagle & 3 \\
Pit Bull Terrier & 3 \\
Brazilian Terrier & 2 \\
Miniature Pinscher & 2 \\
Scottish Terrier & 2 \\
Shih Tzu & 2 \\
English Bulldog & 2 \\
Great Dane & 1 \\
Bernese Mountain Dog & 1 \\
Border Collie & 1 \\
Cane Corso & 1 \\
Doberman Pinscher & 1 \\
Jack Russell Terrier & 1 \\
Rhodesian Ridgeback & 1 \\
Tenerife & 1 \\
West Highland White Terrier & 1 \\
Belgian Shepherd & 1 \\
French Bulldog & 1 \\
Fox Terrier & \\
Pug & 1 \\
Chow Chow & 1 \\
Chinese Shar-pei & 1 \\
Unspecified & 1 \\
\hline
\end{tabular}

Table 3. Histological types of multicentric lymphomas in Brazil according to the WHO classification

\begin{tabular}{|c|c|c|}
\hline Subtype & $\begin{array}{l}\text { Number } \\
\text { of cases }\end{array}$ & Percentage \\
\hline $\begin{array}{l}\text { Precursor } \\
\text { neoplasms }\end{array}$ & & \\
\hline $\begin{array}{l}\text { B-cell lymphoblastic } \\
\text { lymphoma }\end{array}$ & 9 & 4.43 \\
\hline $\begin{array}{l}\text { Mature } \\
\text { neoplasms }\end{array}$ & & \\
\hline $\begin{array}{l}\text { B-cell lymphocytic } \\
\text { lymphoma }\end{array}$ & 4 & 1.97 \\
\hline $\begin{array}{l}\text { Lymphoplasmacytic } \\
\text { lymphoma }\end{array}$ & 4 & 1.97 \\
\hline $\begin{array}{l}\text { Marginal zone B-cell } \\
\text { lymphoma }\end{array}$ & 4 & 1.97 \\
\hline Follicular lymphoma & 2 & 0.98 \\
\hline $\begin{array}{l}\text { Diffuse large B-cell } \\
\text { lymphoma }\end{array}$ & 120 & 59.1 \\
\hline Burkit-Like lymphoma & 1 & 0.49 \\
\hline $\begin{array}{l}\text { Plasmablastic } \\
\text { lymphoma }\end{array}$ & 1 & 0.49 \\
\hline $\begin{array}{l}\text { Precursor } \\
\text { neoplasms }\end{array}$ & & \\
\hline $\begin{array}{l}\text { T-cell lymphoblastic } \\
\text { lymphoma }\end{array}$ & 23 & 11.33 \\
\hline $\begin{array}{ll}\text { Mature } & \text { T-Cell } \\
\text { Neoplasms } & \end{array}$ & & \\
\hline $\begin{array}{l}\text { Peripheral } \\
\text { lymphoma }\end{array}$ & 13 & 6.4 \\
\hline T-zone lymphoma & 18 & 8.86 \\
\hline $\begin{array}{l}\text { Anaplastic } \\
\text { lymphoma }\end{array}$ & 1 & 0.49 \\
\hline Null-cell lymphoma & 3 & 1.47 \\
\hline
\end{tabular}

A study developed in Australia with 134 dogs identified the increased risk of developing lymphomas in Australian Cattle Dog, Doberman, Rottweiler, Boxer and Border Collies dogs (Yau et al., 2017) and a British study with 103 dogs showed high incidence in Boxer, Bulldog and Bull Mastiff (Edwards et al., 2003). Interestingly, the Golden Retriever that is considered the most affected breed in USA and Brazil was not mentioned in these studies. This type of data shows the importance of epidemiological studies and that there may be differences according to geographic region (Edwards et al., 2003; Pastor et al., 2009; Yau et al., 2017).

Studies show patterns of chromosomal changes on B- or T-cell lymphomas that are specific to 
Golden Retrievers, which explain their predisposition to this disease (Modiano et al., 2005). According the WHO classification, diffuse large B-cell lymphoma is the most common in dogs and corresponds to $59.1 \%$ of all cases. These data are congruent to other studies performed on 55, 300 and 992 cases, in which diffuse large B-cell lymphoma was diagnosed in $56.3,48.33$ and $45.86 \%$ of the patients, respectively (Sueiro et al., 2004; Valli et al., 2011, 2013).

Regarding high-grade lymphomas of T-cell origin, the most common histological types in this study were the T-cell lymphoblastic and peripheral T-cell lymphomas, which comprised 11.3 and $6.4 \%$ of the cases, respectively. Highgrade Lymphomas of $\mathrm{T}$-cell origin thus comprised $17.7 \%$ of canine lymphomas in this study. Similar results were found in another study performed on 992 cases, in which highgrade lymphomas were present in $16.6 \%$ of the patients (Valli et al., 2013). In that study, however, peripheral T-cell lymphoma was the most frequent (13.6\%) compared to $\mathrm{T}$ lymphoblastic lymphoma (3\%) (Valli et al., 2013).

Although in the present study there was a predominance of T- lymphoblastic lymphomas compared to peripheral T-cell lymphoma, the differentiation between these two entities is clear through morphological analysis without allowing confusion. Lymphoblastic lymphomas are characterized by intermediate cells and high mitotic index and high ki-67 whereas peripheral T-cell lymphomas present as large lymphocytes and intermediate to high proliferation indices. These differences in histological types may reflect regional variations and suggest different etiological factors, requiring further studies to confirm these findings.

Lymphoma is mostly high-grade in the canine species. However, a part of these is indolent, with slow progression and low proliferative rate (Valli et al., 2013). Follicular, marginal B-zone lymphomas and mantle cell lymphomas are considered B indolent lymphomas by the WHO classification, as well T-zone lymphomas. While these lymphomas are present in 14.5-19.6\% of the cases (Ponce et al., 2010; Valli et al., 2013), there is still little information regarding this group of diseases in the canine species, and studies addressing the current situation in Brazil are still scarce (Sueiro et al., 2004).

The incidence of indolent lymphomas in this study was $11.8 \%$, of which $8.85 \%$ comprise Tzone lymphomas and $1.97 \%$ marginal B-zone lymphomas. These findings corroborate previous studies in which the incidence of indolent lymphomas was $19.6 \%$ (11.2 and $6.5 \%$ for $\mathrm{T}$ zone and marginal B-cell lymphomas, respectively) (Valli et al., 2013). Another study by the same authors showed a $16.4 \%$ incidence of indolent lymphomas, of which $12.7 \%$ were $\mathrm{T}$ zone and $3.7 \%$ were marginal B-zone lymphomas (Valli et al., 2011).

Data from current literature suggest prevalence of B-cell lymphomas over T-cell lymphomas in the canine species (76\% compared to $22 \%$, respectively) (Pawlak et al., 2016). Similar results were reported by recent studies around the world. Modiano et al. (2005) analyzed 518 cases of lymphoma in the United States and found a $67.4 \%$ prevalence of B-cell lymphomas, compared to $30.9 \%$ for T-cell lymphomas. Another study performed on 608 cases from France showed 63.8 and $35.4 \%$ of B-cell and Tcell lymphomas, respectively Ponce et al., (2010). In Poland, 76 cases were assessed and demonstrated $71 \%$ of B-cell lymphomas compared to $17 \%$ of T-cell lymphomas (Pawlak et al., 2016). One study from Germany showed 79.4 and $20.6 \%$ of B- and T-cell lymphomas, respectively (Ernst et al., 2016). All these studies agree with our findings in Brazil, where B-cell lymphomas were diagnosed in $71.4 \%$ compared to T-cell lymphomas in $27.1 \%$ of the cases (Table 4).

A few studies suggest that differences between B- and T-cell distribution might be related to breed due to hereditary risks of the disease (Modiano et al., 2005). In one study of 1226 cases of lymphoproliferative disorders of dogs, 518 patients were diagnosed with non-Hodgkins lymphoma through histopathology. Results showed higher incidence of T-cell lymphomas in Boxers (64.7\% compared to $35.3 \%$ of B-cell lymphomas). Other studies in Europe (Poland and France) also identified that Boxer dogs were more predisposed to the development of $\mathrm{T}$ cell lymphomas compared to other breeds (Pastor et al., 2009; Jankowska et al., 2017). These data differ from this study, in which B-cell lymphoma 
was the most predominant in this breed $(56.3 \%)$, supposing that in Brazil other risk factors may be associated with the development of lymphomas in this breed.

Table 4. Immunophenotype distribution of canine lymphomas according to previous studies from around the world

\begin{tabular}{llll}
\hline Study & $\begin{array}{l}\text { Number of } \\
\text { patients }\end{array}$ & B-cell lymphomas (\%) & T-cell lymphomas (\%) \\
\hline This study (Brazil) & 203 & $71.4 \%$ & $27.1 \%$ \\
Ruslander et al. $(1997)$ & 175 & $76 \%$ & $22 \%$ \\
Modiano et al. $(2005)$ & 518 & $67.4 \%$ & $30.9 \%$ \\
Ponce et al. $(2010)$ & 608 & $63.8 \%$ & $35.4 \%$ \\
Pawlak et al. $(2016)$ & 76 & $71 \%$ & $17 \%$ \\
Ernst et al. $(2016)$ & 411 & $79.4 \%$ & $20.6 \%$ \\
\hline
\end{tabular}

*A few studies included non-B and non-T lymphomas in their analyses and therefore total percentage does not sum up to $100 \%$.

Golden retrievers in this study were associated with mostly T-cell $(57.9 \%)$ compared to B-cell lymphoma $(42.1 \%)$, which contrasts another study showing similar proportions of B- and Tcell origin $(52.3 \%$ and $47.7 \%$, respectively) in 109 patients of this breed (Modiano et al., 2005). A possible explanation for the high incidence of T-lymphomas in the Golden Retrievers in this study was the high proportion of T-zone lymphomas in this breed, which may have contributed to increase the overall proportion of $\mathrm{T}$ lymphomas and once again demonstrating regional variations in the epidemiology of the disease.

Another interesting factor regarding Golden Retrievers is the possible etiological relationship with environmental carcinogens, since the occurrence of indolent T-zone lymphomas in this breed varies with geographical localization (Ruple et al., 2017). A study conducted on 454 Golden Retrievers with T-zone lymphoma (227 cases) and B-cell lymphoma (227 cases) in the United States demonstrated higher prevalence of T-cell lymphoma in the northeast and B-cell lymphoma in the southeast and west (Ruple et al., 2017). This relationship was not assessed by this study, since nearly all samples came from laboratories of the southeast $(83.6 \%)$.

Immunohistochemical analysis of 203 cases of multicentric lymphoma in Brazil showed a $1.5 \%$ incidence of non-B and non- $\mathrm{T}$ lymphomas, which corroborates two studies of 175 and 608 cases demonstrating $2 \%$ and $0.8 \%$ incidence of this subtype, respectively (Ruslander et al., 1997; Ponce et al., 2010). Among the main explanations for this incidence are technical issues, aberrant marking profiles and, also, the possibility of a natural killer cell lymphoma.

\section{CONCLUSION}

Canine multicentric lymphomas in Brazil are similar to canine lymphomas around the world, such as in the United States and Europe, which suggests similar genetic and environmental factors in the etiology of this disease. Despite the prevalence of high-grade lymphomas and the diffuse large B-cell immunophenotype, a small percentage is indolent with distinct characteristics regarding treatment and prognosis, which warrants the need for correct characterization according to the World Health Organization. The author(s) declared no potential conflicts of interest regarding the research, authorship, and/or publication of this article.

\section{REFERENCES}

CURRAN, K.; THAMM, D.H. Retrospective analysis for treatment of naive canine multicentric lymphoma with a 15-week, maintenance free CHOP protocol. Vet. Comp. Oncol., v.14, p.147-155, 2016.

EDWARDS, D.S.; HENLEY, W.E.; HARDING, E.F. et al. Breed incidence of lymphoma in a UK population of insured dogs. Vet. Comp. Oncol., v.1, p.200-206, 2003.

ERNST, T.; KESSLER, M.; LAUTSCHAM, E. et al. Multicentric lymphoma in 411 dogs - an epidemiological study. Tierarztl. Prax. Ausg. K, Kleintiere./Heimtiere, v.44, p.245-251, 2016. 
FLOOD-KNAPIK， K.E.; DURHAM， A.C.; GREGOR, T.P. et al. Clinical. histopathological and immunohistochemical characterization of canine indolentlymphoma. Vet. Comp. Oncol., v.11, p.272-286, 2013.

JAFFE， E.S.; HARRIS， N.L.; STEIN， H.; ISAACSON, P.G. Classification of lymphoid neoplasms: the microscope as a tool for disease discovery. Blood, v.112, p.4384-4399, 2008.

JANKOWSKA, U.; JAGIELSKI, D.; CZOPOWICZ, M.; SAPIERZYŃSKI, R. The animal-dependent risk factors in canine T-cell lymphomas. Vet. Comp. Oncol., v.15, p.307-314, 2017.

LENNERT K.; FELLER, A.C. Histopathology of non-hodgkin's lymphomas. 2.ed. Berlim: Springer Verlag, 1992.

MARCONATO, L.; STEFANELLO, D.; VALENTI, P. et al. Predictors of long term survival in dogs with high grade multicentric lymphoma. J. Am. Vet. Med. Assoc., v.238, p.480-485, 2011.

MODIANO, J.F.; BREEN, M.; BURNETT, R.C. et al. Distinct B-Cell and T-Cell lymphoproliferative disease prevalence among dog breeds indicates heritable risk. Cancer Res., v.65, p.5654-5661, 2005.

Non-Hodgkins's Lymphoma Pathologic Classification Project. National Cancer Institute (NCI) sponsored study of classifications of non-Hodgkin's lymphomas. Cancer v.49, p.2112-2135, 1982.

PASTOR, M.; CHALVET-MONFRAY, K.; MARCHAL, T.; KECK, G. et al. Genetic and environmental risk indicators in canine nonhodgkin's lymphomas: breed associations and geographic distribution of 608 cases diagnosed throughout france over 1 year. J. Vet. Inter. Med., v.23, p.301-310, 2009.

PAWLAK, A.; RAPAK, A.; DRYNDA, A.; PORADOWSKI, D. et al. Immunophenotypic characterization of canine malignant lymphoma: a retrospective study of cases diagnosed in Poland Lower Silesia over the period 20112013. Vet. Comp. Oncol., v.14, p.52-60, 2016.
PONCE, F.; MARCHAL, T.; MAGNOL, J.P. et al. A morphological study of 608 cases of canine malignant lymphoma in France with a focus on comparative similarities between canine and human lymphoma morphology. Vet. Pathol., v.47, p.414-433, 2010.

RUPLE, A.; AVERY, A.C.; MORLEY, P.S. Differences in the geographic distribution of lymphoma subtypes in Golden retrievers in the USA. Vet. Comp. Oncol., v.15, p.1590-1597, 2017.

RUSLANDER, D.A.; GEBHARD, D.H.; TOMPKINS, M.B.; GRINDEM, C.B. et al. Immunophenotypic characterization of canine lymphoproliferative disorders. In Vivo, v.11, p.169-172, 1997.

SUEIRO, F.A.R.; ALESSI, A.C.; VASSALLO, J. Canine lymphomas: a morphological and immunohistochemical study of 55 cases with observations on p53 immunoexpression. $J$. Comp. Pathol., v.131, p.207-213, 2004.

SWERDLOW, S.H.; CAMPO, E.; PILERI, A.S. et al. The 2016 revision of the World Health Organization classification of lymphoid tissue neoplasms. Blood, v.127, p.2375-2390, 2016.

VALLI, V.E. WHO International Histological classification of hematopoietic tumors of domestic animals. Washington: Armed Forces Institute of Pathology, 2002.

VALLI, V.E.; KASS, P.H.; MYINT, M.S.; SCOTT, F. Canine lymphomas: association of classification type. disease stage. tumor subtype. mitotic rate. and treatment with survival. Vet. Pathol., v.50, p.738-748, 2013.

VALLI, V.E.; MYINT, M.S.; BARTHEL, A. et.al. Classification of canine malignant lymphoma according to the World Health Organization criteria. Vet. Pathol., v.48, p.198211, 2011.

VEZZALI, E.; PARODI, A.L.; MARCATO, P.S. et al. Histopathologic classification of 171 cases of canine and feline non Hodgkin lymphoma according to the WHO. Vet. Comp. Oncol., v. 8, p.38-49, 2010.

YAU, P.P.Y.; DHAND, N.K.; THOMSON, P.C.; TAYLOR, R.M. Retrospective study on the occurrence of canine lymphoma and associated breed risks in a population of dogs in NSW (2001-2009). Aust. Vet. J., v.95, p.149-155, 2017. 